\title{
Why the Norwegian shareholder income tax is neutral
}

\author{
Jan Södersten ${ }^{1}$ \\ Published online: 26 April 2019 \\ (c) The Author(s) 2019
}

\begin{abstract}
This note extends the work by Sørensen (Int Tax Public Finance 12:777-801, 2005) and others by demonstrating why the Norwegian Shareholder Income Tax may be neutral between the two sources of equity funds, i.e., new share issues and retained earnings, despite the fact that the retention of earnings to finance new investment does not add to the tax benefits. The analysis crucially relies on the assumption that the deduction for the imputed rate of return is capitalized into the market prices of corporate shares. Absent capitalization, the shareholder tax is rather likely to leave the distortions caused by the double taxation of corporate source income unaffected.
\end{abstract}

Keywords Corporate and shareholder taxation - Tax neutrality · Cost of capital

JEL Classification $\mathrm{H} 24 \cdot \mathrm{H} 25 \cdot \mathrm{H} 32$

\section{The problem}

In 2006, the Norwegian government introduced a new and innovative system for taxing income from corporate shares. The new approach is to exempt dividends and capital gains corresponding to a normal rate of return from tax and to levy a full tax-equal to the personal tax rate on income from capital-on any excess returns. The rate of return allowance (RRA) is computed as the product of the imputation rate, which is the after-tax interest rate, and the stepped-up basis of the share, which is the sum of its acquisition price and all previous unused RRAs.

An in-depth account of the new system has earlier been given by the chief architect of the reform, Peter Birch Sørensen (2005), ${ }^{1}$ and further analysis appears in Alstadsæter and Fjærli (2009), Fjærli and Raknerud (2009), Lindhe and Södersten

\footnotetext{
${ }^{1}$ Sørensen's article was written before the implementation of the new system on January 1, 2006, and is based on a 2003 report from a government-appointed expert committee.

Jan Södersten

Jan.Sodersten@nek.uu.se

1 Department of Economics, Uppsala Center for Fiscal Studies, Uppsala University, Uppsala, Sweden 
(2012), Jacob and Södersten (2013), and Kari and Laitila (2016), as well as in several chapters of the Mirrlees Review (see e.g., Griffith et al. 2010).

The Norwegian Shareholder Tax is seen to avoid the distortionary lock in effect associated with conventional realization-based taxation of capital gains. As the new rules make the tax equivalent to a cash flow tax, the system is also argued to be neutral with respect to firms' investment and financing decisions. However, neither Sørensen nor the other authors quoted above present an explicit analysis of the impact of the tax on the firm's cost of capital. Relying on what is essentially intuitive reasoning is problematic as standard tax models suggest important differences in the impact of shareholder taxes between the two sources of equity funds, i.e., new share issues and retained earnings. As the basis of a corporate share under the Norwegian Shareholder Tax depends on its acquisition price, it is clear that investment projects financed from new share issues will benefit from the new rules. But it is also clear that the retention of earnings to finance new investment does not add to the basis of the shares, that is, to the tax benefits.

This apparent asymmetry therefore seems to indicate that the new rules may well eliminate the tax distortion to the cost of new share issues, but will leave the cost of capital unchanged when the marginal source of funds is retained earnings. The provision that the stepped-up basis of the share includes any unused RRAs (including compound interest) makes no difference to this, as the shareholders neither gain nor lose from postponing the allowance.

This short note derives the firm's cost of capital with the Norwegian Shareholder Tax. Despite the apparent asymmetry in the treatment of the two sources of equity funds, the Shareholder Tax is shown to be neutral, just as claimed by Sørensen et al. The simple and important key to this result-overlooked in previous research-is that a shareholder who chooses to realize the capital gain from the retention of earnings is able to get a higher price for her shares as a result of the future RRAs which the next shareholder may claim on her acquisition cost. This share appreciation exactly offsets the capital gains tax suffered by the original shareholder.

\section{A simple model}

To make the analysis simple, we consider a single investment project of unit value, which is financed either by retained earnings or by a new share issue. We assume that dividends, realized capital gains and interest income are taxed at the rate $\tau$ and we let the stockholder's rate of return requirement be the after-tax interest rate, $i(1-\tau)$. Under the Norwegian Shareholder Tax, the investor is allowed to deduct an imputed rate of return, equal to the after-tax interest rate, on the acquisition cost of the shares against taxable dividends or realized capital gains. The project is undertaken at time 0 , and to capture the effects of capital gains taxation, we assume that the shareholder realizes her gain by selling her part of the project at time $L$, at the 
market price $M(L)$. The buyer (the "next" shareholder) then keeps the asset for the remainder of its (infinite) lifetime. ${ }^{2}$ As in Sorensen et al., we ignore risk.

With retained earnings as the marginal source of funds, the cost to the shareholder of an investment of unit value is $1-\tau$. For the marginal investment, this opportunity cost must equal the present value of the cash flows from the project, that is

$$
1-\tau=\int_{s=0}^{L} D(s)(1-\tau) e^{-i(1-\tau) s} \mathrm{~d} s+M(L)(1-\tau) e^{-i(1-\tau) L},
$$

where the first term on the right-hand side is the flow of after-tax dividends and the second term the proceeds from selling the project at time $L$, net of the capital gains tax. As an investment project financed by retained earnings does not add to the basis of the owner's shares, the rate of return allowance does not (directly) appear in (1).

However, the market value when sold at time $L, M(L)$, must depend on the future cash flows from the project, and their tax treatment. We may assume that

$$
M(L)=\int_{s=L}^{\infty} D(s)(1-\tau) e^{-i(1-\tau)(s-L)} \mathrm{d} s+\int_{s=L}^{\infty} \tau i(1-\tau) M(L) e^{-i(1-\tau)(s-L)} \mathrm{d} s
$$

where the last term, which is equal to $\tau M(L)$, is the share appreciation, at time $L$, arising from the "next" shareholder's rate of return allowances on her acquisition cost.

Combining (1) with (2), we get

$$
1-\tau=\int_{s=0}^{\infty} D(s)(1-\tau) e^{-i(1-\tau) s} \mathrm{~d} s-\tau M(L) e^{-i(1-\tau) L}+\tau M(L) e^{-i(1-\tau) L}
$$

From (3), it is immediately clear that the tax break from the rate of return allowances (last term) exactly offsets the first owner's capital gains tax liability, captured by the middle term. As the tax on dividends (denoted as $\tau$ ) then cancels out from the remaining terms, we finally derive

$$
1=\int_{s=0}^{\infty} D(s) e^{-i(1-\tau) s} \mathrm{~d} s
$$

\footnotetext{
${ }^{2}$ We may alternatively assume a sequence of shareholders, each with a different holding period. This would complicate the analysis but have no effect on the results presented below. For further details, see the Appendix below. See also footnote 3 .
} 
which means that with the shareholder tax, the marginal condition for the investment project is independent of the personal taxation of dividends and capital gains. ${ }^{3}$

With a new share issue as the source of funds, the cost to the shareholder of an investment of unit value equals unity, and we may state the marginal condition as

$$
1=\int_{s=0}^{L} D(s)(1-\tau) e^{-i(1-\tau) s} \mathrm{~d} s+\int_{s=0}^{L} \tau i(1-\tau) e^{-i(1-\tau) s} \mathrm{~d} s+[M(L)-\tau(M(L)-1)] e^{-i(1-\tau) L} .
$$

The new issue of equity (of unity) adds to the basis of the owner's shares, and as a result of this, the owner is entitled to rate of return allowances on the project during her holding period. The accompanying tax savings are captured by the middle term of (5). The last term of (5) shows the after-tax proceeds from selling the project at time $L$, net of the capital gains tax - which in turn is mitigated by the deductibility of the acquisition cost of the project (the amount of the new issue).

The present value in (5) of the tax savings from the rate of return allowances and from the deduction of the project's acquisition cost add up to $\tau$, that is

$$
\int_{s=0}^{L} \tau i(1-\tau) e^{-i(1-\tau) s} \mathrm{~d} s+\tau e^{-i(1-\tau) L} \equiv \tau
$$

Noting this, it is straightforward to show that the marginal condition with new share issues as the source of funds (expression 5) is identical to the marginal condition (expression 1) for the case of retained earnings. The shareholder tax is hence neutral with respect to the two sources of equity funds and-as is apparent from expression (4) - eliminates the impact of personal taxes on the project's marginal condition.

Finally, to obtain a parametric expression for the minimum pre-tax rate of return, i.e., the cost of capital, we may assume that the investment project depreciates exponentially at the rate $\delta$. With $\pi$ as the pre-tax rate of return, the gross profit from the project at time $s$ is then $\pi e^{-\delta s}$, and assuming that corporations are taxed at the rate $\tau$ on their economic profits, the cash flow from the project at time $\mathrm{s}$ is $D(s)=(\pi-\tau(\pi-\delta)) e^{-\delta s}$. Using the marginal condition (4), we then finally derive

$$
\pi-\delta=i
$$

which means that the cost of capital is independent of tax. Hence, we confirm the claim by Sørensen and others that the Norwegian Shareholder Income Tax is neutral.

\footnotetext{
3 The same result is obtained if the original shareholder were to keep the asset forever. In this case, no capital gains tax is paid, leaving the dividend tax as the only tax to consider. It is straightforward to show then that the dividend tax cancels out from the marginal condition.
} 


\section{Conclusion}

This short note has extended the work by Sørensen and others by demonstrating why the Norwegian shareholder income tax may be neutral between the two sources of equity funds, i.e., new share issues and retained earnings. The analysis crucially relies on the assumption that the deduction for the imputed return is capitalized into the market prices of corporate shares. Despite the fact that the retention of earnings to finance a new investment project does not add to the basis of corporate shares, that is, to the tax benefits, the share appreciation deriving from the RRAs enjoyed by future shareholders offsets any capital gains tax suffered by the current shareholders. Absent capitalization, the shareholder tax is rather likely to leave the distortions caused by the double taxation of corporate source income unaffected. ${ }^{4}$

Acknowledgements Jan Södersten is grateful to Seppo Kari for helpful suggestions.

Open Access This article is distributed under the terms of the Creative Commons Attribution 4.0 International License (http://creativecommons.org/licenses/by/4.0/), which permits unrestricted use, distribution, and reproduction in any medium, provided you give appropriate credit to the original author(s) and the source, provide a link to the Creative Commons license, and indicate if changes were made.

\section{Appendix}

Suppose that the second owner considered above instead sells the asset at time $L_{1}$. Expression (2) is then replaced by

$$
\begin{aligned}
M(L)= & \int_{s=L}^{L_{1}} D(s)(1-\tau) e^{-i(1-\tau)(s-L)} \mathrm{d} s+\int_{s=L}^{L_{1}} \tau i(1-\tau) M(L) e^{-i(1-\tau)(s-L)} \mathrm{d} s \\
& +\left[M\left(L_{1}\right)(1-\tau)+\tau M(L)\right] e^{-i(1-\tau)\left(L_{1}-L\right)}
\end{aligned}
$$

since the acquisition cost $M(L)$ is the base for rate of return allowances over the holding period $L_{1}-L$ and is also deductible for capital gains taxation. In the same way,

$$
\begin{aligned}
M\left(L_{1}\right)= & \int_{s=L_{1}}^{L_{2}} D(s)(1-\tau) e^{-i(1-\tau)\left(s-L_{1}\right)} \mathrm{d} s+\int_{s=L_{1}}^{L_{2}} \tau i(1-\tau) M\left(L_{1}\right) e^{-i(1-\tau)\left(s-L_{1}\right)} \mathrm{d} s \\
& +\left[M\left(L_{2}\right)(1-\tau)+\tau M\left(L_{1}\right)\right] e^{-i(1-\tau)\left(L_{2}-L_{1}\right)}
\end{aligned}
$$

and

\footnotetext{
${ }^{4}$ For further discussion, see Lindhe and Södersten (2012) and Jacob and Södersten (2013), who view the shareholder income tax as a closed economy construct.
} 


$$
\begin{aligned}
M\left(L_{2}\right)= & \int_{s=L_{2}}^{L_{3}} D(s)(1-\tau) e^{-i(1-\tau)\left(s-L_{2}\right)} \mathrm{d} s+\int_{s=L_{2}}^{L_{3}} \tau i(1-\tau) M\left(L_{2}\right) e^{-i(1-\tau)\left(s-L_{2}\right)} \mathrm{d} s \\
& +\left[M\left(L_{3}\right)(1-\tau)+\tau M\left(L_{2}\right)\right] e^{-i(1-\tau)\left(L_{3}-L_{2}\right)}
\end{aligned}
$$

assuming that the third owner sells the asset at time $L_{2}$, and the fourth owner at time $L_{3}$.

Using $(2 *),(2 * *)$ and $(2 * * *)$, expression (1) turns into

$$
1-\tau=\int_{s=0}^{L_{3}} D(s)(1-\tau) e^{-i(1-\tau) s} \mathrm{~d} s+M\left(L_{3}\right)(1-\tau) e^{-i(1-\tau) L_{3}}
$$

Hence, given $L_{3}$, the number and length of preceding sub-periods is of no importance. Moreover, extending $L_{3}$ indefinitely, that is $L_{3} \rightarrow \infty$, turns ( $\left.1^{*}\right)$ into expression (4) above.

\section{References}

Alstadsæter, A., \& Fjærli, E. (2009). Neutral taxation of shareholder income? Corporate responses to an announced dividend tax. International Tax and Public Finance, 16, 571-604.

Fjærli E, Raknerud A (2009) The investment and financing decisions of closely held firms when there is a tax on the equity premium. Discussion Papers No. 594, September 2009, Statistics Norway, Research Department.

Griffith, R., Hines, J., \& Sørensen, P. B. (2010). International Capital Taxation. Chapter 10, in Dimensions of Tax Design, Mirrlees Review. www.ifs.org.uk/publications/mirrleesreview.

Jacob, M., \& Södersten, J. (2013). Mitigating shareholder taxation in small open economies? Finnish Economic Papers, 26(1), 1-12.

Kari, S., \& Laitila, J. (2016). Rate-of-return allowance in a growth model of the firm-a further justification for the carry-forward rules. Mimeo, VATT Institute for Economic Research, Helsinki, Finland.

Lindhe, T., \& Södersten, J. (2012). The Norwegian shareholder tax reconsidered. International Tax and Public Finance, 19, 424-441.

Sørensen, P. B. (2005). Neutral taxation of shareholder income. International Tax and Public Finance, 12, 777-801. 